\title{
Changing the Nutrient Source from Ammonia to Nitrate: Effects on Heterotrophic Bacterial Growth in Wastewater
}

\author{
Xin-Yan Zhang ${ }^{1,2 *}$, Dang-Cong Peng ${ }^{2}$, Qiong Wan ${ }^{1}$, Kai Ju ${ }^{1}$, Bin-Bin Wang ${ }^{3}$, \\ Li-Ying Pei ${ }^{2}$, Yin-Ping Hou ${ }^{2}$ \\ ${ }^{1}$ College of Architecture and Civil Engineering, Xi' an University of Science and Technology, Xi'an, China \\ ${ }^{2}$ Department of Environmental and Municipal Engineering, Xi' an University of Architecture and Technology, \\ Xi'an, China \\ ${ }^{3}$ College of Environment, Zhejiang University of Technology, Hangzhou, Zhejiang, China
}

Received: 5 March 2019

Accepted: 7 May 2019

\begin{abstract}
Bacteria can use nitrate as a nutrient for growth, but the underlying mechanisms of this pathway have not yet been identified. We investigated the effects of changing the nitrogen source from ammonia to nitrate on the properties of heterotrophic bacterial growth in anoxic and anoxic/oxic (A/O) SBRs. Both SBR types were seeded with activated sludge cultivated with ammonia and were then fed with $1,400 \mathrm{mg} \cdot \mathrm{L}^{-1}$ chemical oxygen demand (COD) and $250 \mathrm{mg} \cdot \mathrm{L}^{-1}$ of nitrate nitrogen. Heterotrophic bacteria had a lag period of 8-9 $d$ and 13-14 $d$ in terms of growth and COD and nitrogen removal, respectively, in both reactors with nitrate as nutrient. Of the influent nitrate, $15 \%$ were converted to biomass nitrogen. Compared with ammonia or organic nitrogen as a nutrient source, with the use of nitrate more energy was needed for proteins synthesis, which resulted in a lower sludge yield (0.32-0.35) and lower amounts of proteins and phosphorus compounds. Furthermore, fewer extracellular polymer substances (EPS) and more soluble microbial products (SMP) were produced, both of which also had low proteins and high polysaccharide contents. The proteins in the cells were synthesized via dissimilatory nitrate reduction to ammonia (DNRA).
\end{abstract}

Keywords: denitrification, nitrogen source, dissimilatory nitrate reduction to ammonia, nitrate assimilation, sludge yield

*e-mail:zhangxinyan126@163.com 


\section{Introduction}

In municipal wastewater treatment plants (WWTP), denitrification is the main pathway for nitrogen removal. However, it is still unclear whether nitrate is used as a nitrogen source as well as a terminal electron acceptor.

Nitrate as the sole nitrogen source for bacterial growth has been reported in sulfur-oxidizing bacteria [1-3], Methanococcus thermolithotrophicus [4], and activated sludge [5]. The common pathway is the dissimilatory nitrate reduction to ammonia (DNRA). DNRA bacteria reduce nitrate to ammonia in a dissimilar way, the produced ammonia is then used by other bacterial species for growth. Activated sludge with nitrate as a nutrient source can perform as well as sludge with ammonia as a nutrient source in organic and nitrogen removal [5]. The use of nitrate also results in lower biomass yield compared to the use of ammonia [5-7], thereby reducing the costs of subsequent sludge handling and disposal. In this context, it is crucial to know the characteristics of activated sludge with nitrate as a nutrient source and the influence of DNRA on overall nitrate reduction.

In soil, DNRA is a widespread process [8], but this process has also been reported in freshwater [9, 10], marine systems [11], anammox bacteria [12-14], human feces [15], digested sludge [16, 17], and constructed wetlands [18]. Bacteria carrying out this process may also occur in activated sludge, potentially contributing to nitrate reduction. High $\mathrm{C} / \mathrm{N}$ ratio and nitrate limitation favours nitrate reduction to ammonia via DNRA [6]. Will DNRA occur when the environment is full of nitrates and organics without ammonia?

In this context, this study was designed (1) to investigate the properties of heterotrophic bacteria from anoxic and anoxic/oxic (A/O) SBRs, using nitrate as the sole nitrogen source for growth; (2) to investigate whether these bacteria reduce nitrate via the DNRA pathway; and (3) to compare the differences between bacterial growth in the anoxic/oxic reactor and in the anoxic reactor.

\section{Materials and Methods}

\section{Experimental System and Operation}

Two parallel SBRs with a working volume of $5 \mathrm{~L}$ each were used for the cultivation of denitrifying activated sludge. The A/O SBR was operated at an anoxic/oxic cycle, and the anoxic SBR was a complete anoxic system. Both reactors were inoculated with activated sludge from a wastewater treatment plant in Xi'an. Synthetic wastewater, which was used as an influent for both reactors, had the following composition: $1,400 \mathrm{mg}$ COD $\cdot \mathrm{L}^{-1}$ (glucose), $250 \mathrm{mg}$ $\mathrm{NO}_{3}{ }^{-}-\mathrm{N} \cdot \mathrm{L}^{-1}$ (sodium nitrate), $12 \mathrm{mg} \mathrm{PO}_{4}^{3-}-\mathrm{P} \cdot \mathrm{L}^{-1}\left(\mathrm{KH}_{2} \mathrm{PO}_{4}\right)$, $90 \mathrm{mg} \cdot \mathrm{L}^{-1}$ of $\mathrm{MgSO}_{4} \cdot 7 \mathrm{H}_{2} \mathrm{O}, 14 \mathrm{mg} \cdot \mathrm{L}^{-1}$ of $\mathrm{CaCl}_{2} \cdot 5 \mathrm{H}_{2} \mathrm{O}$, and $0.3 \mathrm{~mL}$ of the trace element solution (per liter): $0.12 \mathrm{mg} \cdot \mathrm{L}^{-1}$ of $\mathrm{ZnSO}_{4} \cdot 7 \mathrm{H}_{2} \mathrm{O}, 0.12 \mathrm{~g}$ of $\mathrm{MnCl}_{2} \cdot \mathrm{H}_{2} \mathrm{O}, 7.5 \mathrm{~g}$ of $\mathrm{FeSO}_{4} \cdot 7 \mathrm{H}_{2} \mathrm{O}, 0.15 \mathrm{~g}$ of $\mathrm{H}_{3} \mathrm{BO}_{3} 0.03 \mathrm{~g}$ of $\mathrm{CuSO}_{4} \cdot 5 \mathrm{H}_{2} \mathrm{O}$, $0.18 \mathrm{~g}$ of KI, $0.06 \mathrm{~g}$ of $\mathrm{Na}_{2} \mathrm{MoO}_{4} \cdot 2 \mathrm{H}_{2} \mathrm{O}, 0.15 \mathrm{~g}$ of $\mathrm{CoCl}_{2}$. The $\mathrm{pH}$ was kept between 7.6 and 8.0 by adding $\mathrm{H}_{2} \mathrm{CO}_{3} / \mathrm{HCO}_{3}^{-}$buffer solution, which was prepared by mixing $\mathrm{HCL}$ with $\mathrm{NaHCO}_{3}$. The temperature in the SBRs was maintained at $25 \pm 2^{\circ} \mathrm{C}$. A cycle time of $6 \mathrm{~h}$ was operated for the A/O SBR in a sequential mode: 2 min influent feeding without mixing, $178 \mathrm{~min}$ mixing under anoxic conditions, $60 \mathrm{~min}$ of mixing under aerobic conditions, $20 \mathrm{~min}$ of settling, $2 \mathrm{~min}$ of discharging, and 98 min of idling. The anoxic SBR was operated at $2 \mathrm{~min}$ of feeding without mixing, $238 \mathrm{~min}$ of mixing under anoxic conditions, $20 \mathrm{~min}$ of settling, 2 min of discharging, and $98 \mathrm{~min}$ of idling. The $\mathrm{pH}$ probe (METTLER InPro 4010, Germany) and the DO probe (METTLER Inpro 6050, Germany) were monitored online. The exchange ratio was controlled at 0.5 , which corresponded to $12 \mathrm{~h}$ of hydraulic retention time (HRT); sludge retention time (SRT) was $10 \mathrm{~d}$ through discharging $500 \mathrm{ml}$ liquid mixture daily.

\section{Nitrate Conversion Pathway Experiments}

We evaluated the influent nitrate conversion pathway on days $1,14,35$, and 60 . The experiment was carried out in an airtight reactor. The flow of argon to the reactor was maintained at $50 \mathrm{~mL} \cdot \mathrm{min}^{-1}$ for 5 min using a mass flow controller to evacuate all the air and nitrogen in the reactors prior to the experiment. Subsequently, the reactors were sealed with silicone rubber stoppers. The concentration of volatile suspended solids (VSS) was used for biomass determination. Samples for $\mathrm{N}_{2} \mathrm{O}$ and $\mathrm{N}_{2}$ determination were collected directly from the headspace gas. The culture sample was harvested via centrifuge at $10,000 \mathrm{~g}$ for $10 \mathrm{~min}$, and the sludge was washed with pure water and further dried to constant weight at $102 \pm 2^{\circ} \mathrm{C}$ for $6 \mathrm{~h}$ in order to analyze SS, VSS, total Kjeldahl nitrogen (TKN), total phosphorus, and lipids, according to the standard methods. The supernatant was filtered through $0.22-\mu \mathrm{m}$ disposable Sartorius filters to separate any residual biomass for the analysis of soluble chemical oxygen demand (SCOD), $\mathrm{NO}_{3}^{-}-\mathrm{N}, \mathrm{NH}_{4}^{+}-\mathrm{N}$, and $\mathrm{NO}_{2}^{-}-\mathrm{N}$, according to the standard methods for wastewater analysis [19].

To determine the concentrations of denitrification end products $\left(\mathrm{N}_{2} \mathrm{O}\right.$ and $\left.\mathrm{N}_{2}\right), \mathrm{N}_{2} \mathrm{O}$ mole fractions, denitrification rate $\left(\mathrm{N}_{2}\right.$ and $\left.\mathrm{N}_{2} \mathrm{O}\right)$, DNRA rate, total $\mathrm{NO}_{3}$ consumption, denitrification/total $\mathrm{NO}_{3}^{-}$consumption ratio, and DNRA/total $\mathrm{NO}_{3}{ }^{-}$consumption ratio were examined, along with their interactions.

\section{Gas Analysis}

We sampled $20 \mathrm{~mL}$ of headspace gas with a syringe and injected them into re-evacuated $20 \mathrm{~mL}$-glass vials. The concentration of $\mathrm{N}_{2} \mathrm{O}$ was measured using a gas 
chromatograph (PE Clause 600) equipped with an electron capture detector (ECD) and packed columns (Porapak Q). The $\mathrm{N}_{2}$ concentration of the gas sample was analyzed via a gas chromatograph (Agilent 6890N) equipped with a thermal conductivity detector (TCD) and stainless steel packed columns of TDX-01.

\section{Analysis of Extracellular Polymeric Substance} (EPS) and Soluble Microbial Products (SMP)

Soluble microbial products are defined as the pool of organic compounds from metabolism processes and biomass decay and are released into the solution. Total SMP was determined as follows:

$$
\begin{gathered}
\mathrm{SMP}=\text { soluble polysaccharide (as glucose) } \\
+ \text { soluble nucleic (as CT DNRA) }
\end{gathered}
$$

The EPS of the sludge samples were extracted according to the cation-exchange resin technique (Dowex Marathon C, 20-50 mesh, sodium form, Fluka 91973) proposed by FRØLUND and WANG [20, 21]. The major components of EPS and SMP, including proteins, polysaccharides, and humic compounds, were quantified separately by colorimetric methods. The protein concentration was determined according to the method described by the modified Lowry method [22], bovine serum albumin (V900933, Vetec ${ }^{\mathrm{TM}}$, Sigma-Aldrich ) was used as standard, and the results are expressed in $\mathrm{mg}$ equivalent of BSA per gram of adsorbent. Polysaccharide concentration was measured by the phenol sulfuric acid method described by [23] Dubois et al., glucose (V900392, Vetec, Sigma-Aldrich) was used as standard, and the results are expressed in $\mathrm{mg}$ equivalent of glucose per gram of adsorbent. The nucleic acid content was measured via the diphenylamine colorimetric method using calf thymus DNA (D4522, Vetec, Sigma-Aldrich) as standard [24]. Total EPS was determined as follows:

$\mathrm{EPS}=$ proteins (as BSA) + polysaccharides

\section{Nitrate Conversion Pathway}

On day 60, activated sludge was sampled from both reactors and washed with pure water to remove other nitrogen compounds in the supernatant. If the sole nitrogen source of the influent is nitrate, the isotopic method is not required for the analysis of the nitrate conversion pathway. Subsequently, the sludge samples were placed into two $100-\mathrm{mL}$ serum bottles. In this experiment, the influent $\mathrm{C} / \mathrm{N}$ was increased to 7 , facilitating DNRA. The detection of ammonia indicated that the bacteria reduced nitrate via the DNRA pathway; if ammonia was absent, the assimilatory pathway was used.
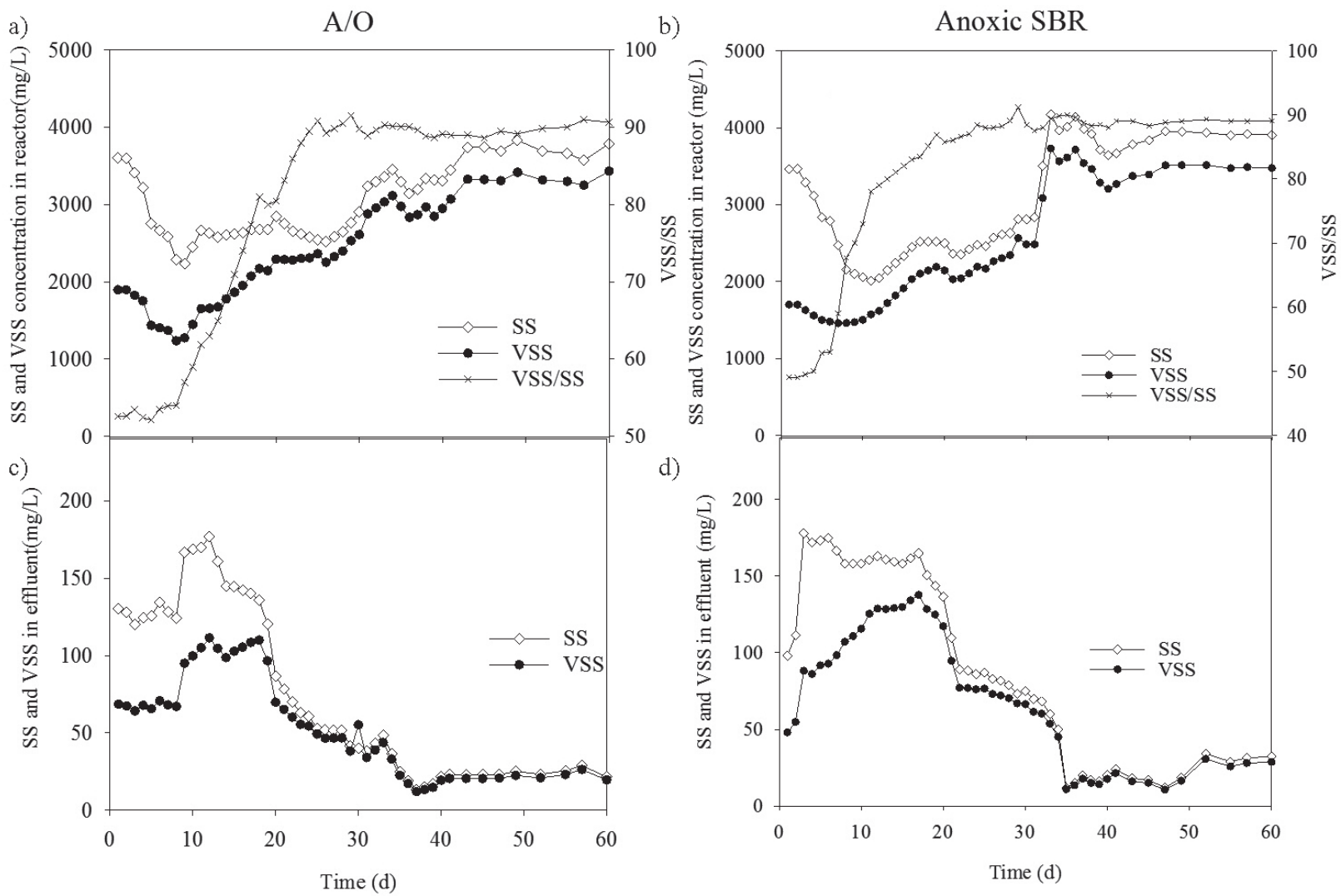

Fig. 1. Variation of concentrations in SS, VSS, and VSS/SS: a) and b) SS, VSS, and VSS/SS in reactors; c) and d) SS and VSS in the effluent. 


\section{Results and Discussion}

\section{Effects of Changing Nutrients on Bacterial Growth}

The experiment lasted for $60 \mathrm{~d}$, with an influent COD of $1,400 \mathrm{mg} \cdot \mathrm{L}^{-1}$ (glucose) and $250 \mathrm{mg} \cdot \mathrm{L}^{-1}$ nitrate nitrogen (sodium nitrate). The nitrogen source of the seed sludge was organic or ammonia nitrogen. Fig. 1(a-b) shows the similar trends of SS and VSS concentrations with changing nitrogen sources from ammonia to nitrate. Bacterial growth showed a lag period of 8-9 days in both reactors due to the changes in the nitrogen source. However, Boopathy and Kulpa [7] reported long lag periods in the growth rates of sulfate-reducing bacteria when TNT or nitrite was used as the nitrogen source, but no lag phase was observed when nitrate was the sole nitrogen source. It is well known that lag stages have also been observed in pure cultures. Microorganisms need time to adapt to a new matrix environment. At the beginning of the experiment, bacteria that used nitrate as a nutrient did not dominate the seed sludge, and the SS level decreased quickly. In both reactors, SS levels started to increase after $9 \mathrm{~d}$, regardless of the dramatic sludge washing out (Fig. 1c, d). Results indicated that the microorganisms adapted to nitrate as the sole nitrogen source, with rapid growth rates.

Experimental work supports how the substrate types and operation systems affect sludge yield. In this study, the observed heterotrophic yields were $0.35 \mathrm{~g} \mathrm{COD} \cdot \mathrm{g}$ $\mathrm{COD}^{-1}$ for A/O SBR and $0.30 \mathrm{~g} \mathrm{COD} \cdot \mathrm{g} \mathrm{COD}^{-1}$ for the anoxic SBR. Belay et al. [4] and Boopathy and Kulpa [7] also reported that nitrate as the sole nitrogen source resulted in 20-25\% lower sludge yield than ammonia for sulfate-reducing bacteria and Methanococcus. However, Van den Berg et al. [6] reported the DNRA had little effect on the biomass yields ( 0.47 and 0.45 for denitrification and DNRA periods, respectively). The observed biomass yield factor is a function of the maximum biomass yield, the sludge decay rate and the sludge retention time [25]. In principle, bacteria need more energy to reduce $\mathrm{NO}_{3}^{-}$to ammonia and, subsequently, to synthesize new cells than they would need for cell synthesis from ammonia or organic nitrogen. Consequently, nitrate as the sole nitrogen source results in lower sludge yield than ammonia as the nitrogen source. In addition, the A/O sludge yield was higher than that of the anoxic sludge using nitrate. The low yield of heterotrophic bacteria in this study resulted from low ammonia concentration for bacterial growth due to low DNRA rate and more COD needed for bacterial growth with nitrate.

Effect of Changing Nutrients on Sludge Performance in Terms of COD and Nitrogen Removal

The activated sludge in both reactors displayed a

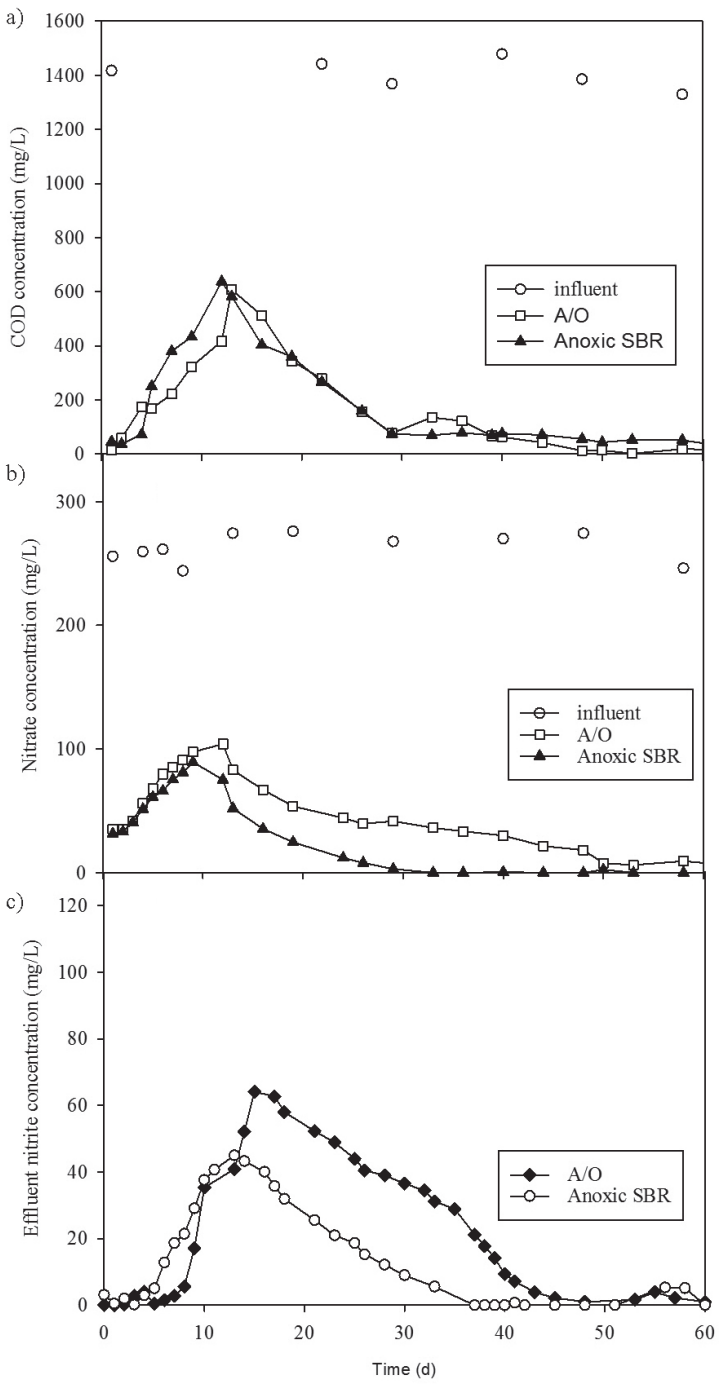

Fig. 2. Performance of reactors over time a) Concentration profiles of $\mathrm{COD}$; b) Concentration profiles of nitrate; c) Concentration profiles of nitrite.

lag period of 13-15 days in terms of COD and nitrate removal (Fig. 2). The COD removal efficiency decreased from 99 and $96 \%$ at the start of the experiment to 71 and $70 \%$ on day 13 in the A/O SBR and the anoxic SBR, respectively (Fig. 2a). We also observed a significant decrease in TN removal (from 70 to $39 \%$ for $\mathrm{A} / \mathrm{O}$ and to $51 \%$ for the anoxic SBR) due to the changes in the nitrogen source, and the accumulated nitrite was as high as 64 and $45 \mathrm{mg} \cdot \mathrm{L}^{-1}$, respectively, on day 13 . Afterward, COD and nitrogen removal improved gradually in both reactors. At the end of the experiment, COD and TN removal efficiencies were as high as 99 and $84 \%$ for the A/O SBR and 97 and $87 \%$ for the anoxic SBR, respectively. This shows that the sludge with nitrate as nutrient performed as well as the conventional activated sludge (seed sludge) with ammonia. Fig. 2c shows that the $\mathrm{A} / \mathrm{O}$ process results in higher nitrite accumulation than the anoxic process. The substrate was degraded by aerobic organisms, so less nitrate was reduced to $\mathrm{N}_{2}$ or $\mathrm{NH}_{4}^{+}$, and nitrite levels were higher in the A/O SBR. 
Endogenous respiration results in some biomass decay as well as in ammonification and nitrification.

\section{Effect of Changing Nutrients on Sludge Components}

To compare the properties of sludge cultivated in different nitrogen media and at different operation processes, we determined the components of seed sludge and experimental sludge on day 60 . The results showed that protein synthesis was not affected by the operation process, but the synthesis of polysaccharides, phosphorus, and lipid substances was significantly affected (Fig. 3a). Higher polysaccharides and phosphorus compounds were synthesized in A/O sludge compared to anoxic sludge, while the amounts of lipids were relatively low. It should be noted that the proteins content was more significantly affected by the nitrogen source. Nitrate as nitrogen source had a negative effect on the synthesis of cell proteins and phosphorus compounds, but a positive effect on polysaccharides and lipids synthesis. Compared with the anoxic process, the A/O process had a positive effect on polysaccharides synthesis and a negative effect on lipid synthesis.
The sludge proteins contents were significantly affected by the nitrogen source, and the proteins contents in the experimental sludge were determined in terms of nitrogen content. The nitrogen content of the sludge markedly decreased from $10-11 \%$ to 4.64 and $5.10 \%$ within 7 days, which was induced by the change of the nitrogen source (Fig. 3b). As a result, cell growth was highly inhibited. After 8 days of cultivation, the nitrogen content gradually increased and stabilized at $8.6 \%$ in VSS until the end of the experiment. At this time, the nitrogen content was significantly lower than that of the activated sludge from WWTP (11-13\%), if considering that the formula $\mathrm{C}_{5} \mathrm{H}_{7} \mathrm{NO}_{2}$ is representative for cell mass. It was also lower than that of the anoxic/ aerobic activated sludge $(10.5-12.5 \%)$ [26] and the seed sludge from WWTP(10.3\%). A previous study [6] reported that the nitrogen content of biomass is $12.3 \%$ in a continuous culture-enriching of DNRA bacteria. Under the condition of nitate as sole nitrogen source and low DNRA rate, there was not enough ammonia for growth. Microbes had to use endogenous organics such as some proteins or other nitrogen-containing organic from activated sludge and EPS, and these nitrogencontaining groups were released into the system in the
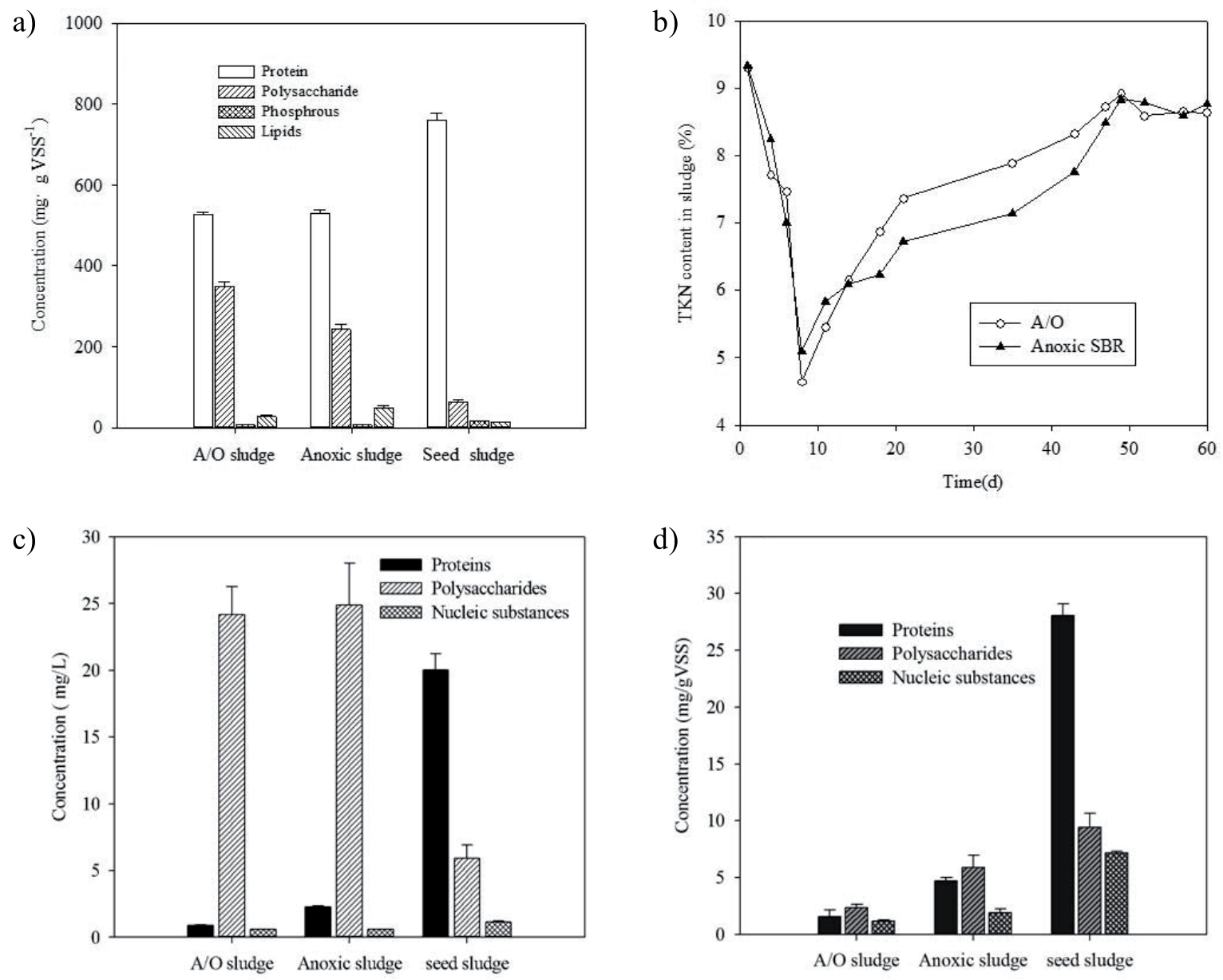

Fig. 3. a) Components and contents of A/O sludge, anoxic sludge and seed sludge; b) Variation of protein content in the experimental sludge during change of nitrogen source; c) EPS and d) SMP produced in experimental sludge and seed sludge. 
utilization process, thus the nitrogen in activated sludge was low.

\section{Effect of Changing Nutrients on the Production of EPS and SMP}

EPS and SMP are secreted by cells, which are important for the performance of the sludge and can be affected by insufficient essential nutrients [27]. The proteins content was well known as being much higher than the polysaccharides content. The EPS and SMP of the seed sludge, the A/O sludge, and the anoxic sludge under steady state were evaluated to investigate the effect of changing the nitrogen source. As shown in Fig. 3, the proteins contents in the sludge, in EPS, and in SMP were lower than that in the seed sludge; for the polysaccharides content, an opposite trend was observed. The amount of SMP was significantly higher in A/O and anoxic SBRs with nitrate as the sole nitrogen source, compared to the seed sludge with ammonia as the nutrient. This indicates that the use of nitrate as nutrient results in a higher SMP production, especially in terms of polysaccharide production; while the production of proteins and nucleic substances was significantly lower compared to the medium with ammonia as nutrient. The total contents of EPS in both reactors were considerably lower than those in the seed sludge, although EPS had similar components than SMP; polysaccharides, in contrast to proteins, constituted a larger fraction of EPS in the experimental sludge. The proteins/polysaccharides (PN/PS) ratios were as low as 0.67 and 0.79 in $\mathrm{A} / \mathrm{O}$ and anoxic sludge, respectively, which were lower than DEAMOX-UASB sludge (4-9) [28], anammox dominated in mix culture (2.92) [29] and conventional activated sludge (2.2-2.9) [30]. It was speculated that the increase of PS component in the EPS and SMP was due to long-term lack of ammonia as a nitrogen source for bacterial growth. The influent $\mathrm{C} / \mathrm{N}$ ratio of SBRs was low, which is a benefit for denitrification over DNRA. So the ammonia produced via DNRA was deficient for bacterial growth. Microorganisms used the proteins in EPS and SMP as nitrogen source for growth. Although the biomass growth exhibited a lag period, the bacterial growth rate and the denitrification capacity were hardly affected in the treatment with nitrate as nutrient. However, the cell components and the microbial products were considerably affected.

\section{Nitrogen Mass Balance Analysis}

The nitrogen mass balance is important for understanding the conversion of the influent nitrate during the change of the nitrogen source. Samples were taken from the experimental reactors on days 1 , 13,35 , and 60 to determine the nitrogen mass balance, which was measured by evaluating the input and output nitrogen fluxes in a typical period. Typical relative distributions of nitrogen are shown in Fig. 4. The stoichiometry equations calculated from the $\mathrm{N}$ mass balance based on the change of different $\mathrm{N}$ in the reactor were as follows.

For the bacteria of seed sludge in A/O SBR with ammonia as nutrient and nitrate as terminal electron acceptor:

$$
\mathrm{NO}_{3}^{-} \rightarrow 0.137 \mathrm{NO}_{3}^{-}+0.0035 \mathrm{~N}_{2} \mathrm{O}+0.408 \mathrm{~N}_{2}+0.039 \mathrm{~N}_{\text {cell }}
$$

For the bacteria in A/O SBR using nitrate as sole nitrogen source for growth and denitrification:

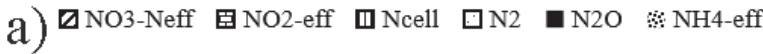

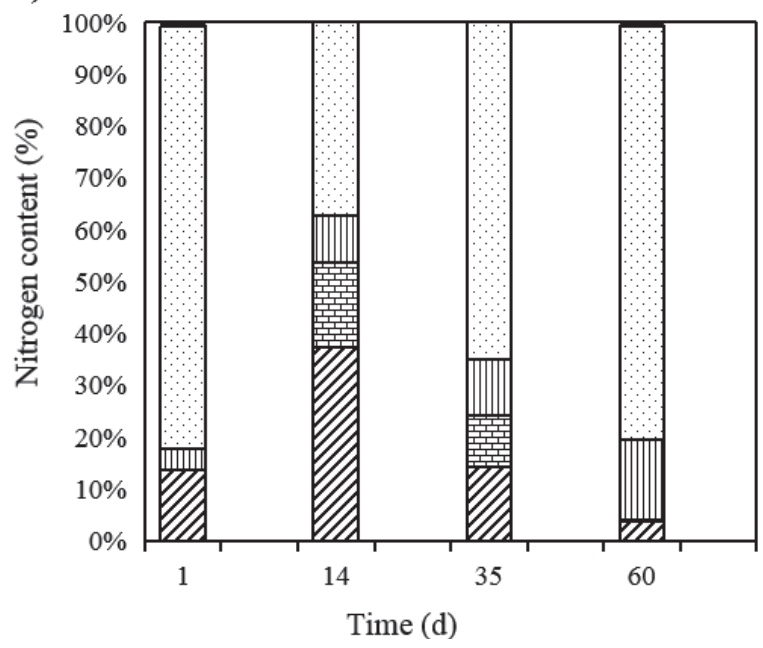

b)

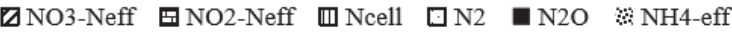

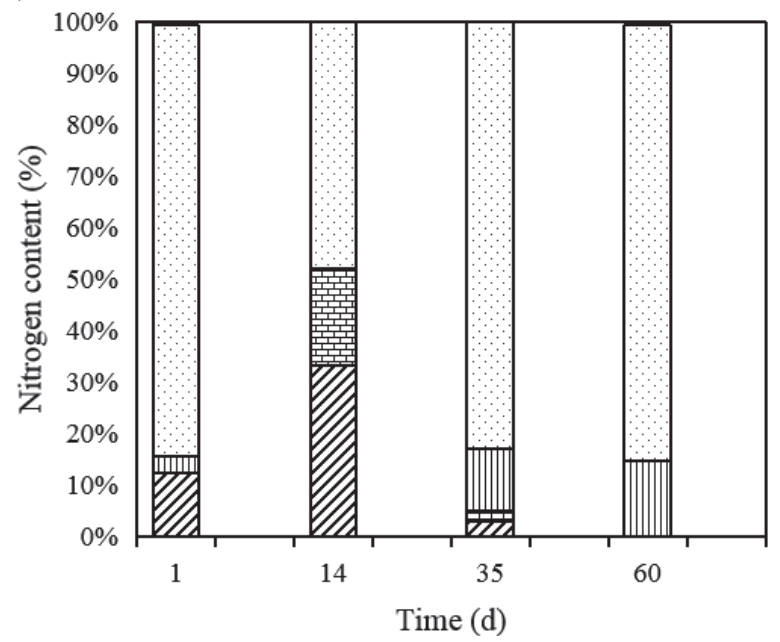

Fig. 4. Mass balance for nitrogen in the A/O SBR a) and the anoxic SBR b) on days 1, 14, 35, and 60 . The heights of the bars indicate the $\mathrm{NO}_{3}{ }_{3}^{-}$concentration converted in the reactor. Heights of different parts of bars represent fractions of concentrations of specific compounds relative to the amount of converted $\mathrm{NO}_{3}^{-}$. Where $\mathrm{NO}_{3}{ }^{-} \mathrm{Neff}$ is effluent nitrate concentration, $\mathrm{NO}_{2}$ - $\mathrm{Neff}$ is effluent nitrite concentration, Ncell is nitrogen content in bacterial cell, $\mathrm{N}_{2}$ and $\mathrm{N}_{2} \mathrm{O}$ represent the nitrogen in gas emitted by denitrification or DNRA. 
$\mathrm{NO}_{3}^{-} \rightarrow 0.036 \mathrm{NO}_{3}^{-}+0.004 \mathrm{NO}_{2}^{-}-+0.0035 \mathrm{~N}_{2} \mathrm{O}+0.398 \mathrm{~N}_{2}+0.156 \mathrm{~N}_{\text {cell }}$

For the bacteria of seed sludge in anoxic SBR with ammonia as nutrient and nitrate as terminal electron acceptor:

$\mathrm{NO}_{3}^{-} \rightarrow 0.122 \mathrm{NO}_{3}^{-}+0.002 \mathrm{NO}_{2}^{-}+0.0035 \mathrm{~N}_{2} \mathrm{O}+0.419 \mathrm{~N}_{2}+0.032 \mathrm{~N}_{\text {cell }}$

For the bacteria in anoxic SBR using nitrate as sole nitrogen source for growth and denitrification:

$$
\mathrm{NO}_{3}^{-} \rightarrow 0.0035 \mathrm{~N}_{2} \mathrm{O}+0.422 \mathrm{~N}_{2}+0.147 \mathrm{~N}_{\text {cell }}
$$

No ammonia was detected during the entire study period. It is speculated that the ammonia nitrogen produced by microorganisms through DNRA was removed by biomass growth. At the beginning of the experiment, only $3.2-3.9 \%$ of the influent nitrate was converted to cell proteins, but the ratio increased up to 15.5 and $14.7 \%$ for the A/O SBR and the anoxic SBR, respectively, after 60 days of operation. At this time, 81 and $84 \%$ of the influent nitrate were reduced to $\mathrm{N}_{2}$ by denitrification. Using the stoichiometry equation, it was predicated that $18 \%$ of the influent nitrate would be converted into organic nitrogen, while the rest would be converted into nitrogen gas [31]. Obviously, the theoretical value from the stoichiometry equation, for this case, is higher than the experimental value. The process DNRA is favored in environments with a high $\mathrm{C} / \mathrm{N}$ ratio [10]; it is therefore more competitive than denitrification in environments rich in organic matter and poor in nitrate. The study of Roland et al. [32] focused on the co-occurrence of denitrification, anammox, and DNRA in a tropical freshwater lake and on the influence of $\mathrm{H}_{2} \mathrm{~S}$ on these three processes. At a $\mathrm{C} / \mathrm{N}$ ratio of 7.7, $90 \%$ of nitrate was recovered in ammonia and biomass [6]. A high $\mathrm{C} / \mathrm{N}$ ratio and nitrogen efficiency [6], temperature [33], $\mathrm{pH}$ [10] nitrogen source, and redox potential [34], a low DO and cathode potentials [35], the presence of sulfide and $\mathrm{Fe}^{2+}$, and high salinity [36] are potentially important environmental controls in the competition of denitrifying and DNRA bacteria. The impacts on the $\mathrm{C} / \mathrm{N}$ ratio, redox potential, nitrogen efficiency, cathode potentials, sulfide, and $\mathrm{Fe}^{2+}$, as well as the low DO on this competition result in an increased ratio of electron donors to acceptors, thereby decreasing the bottleneck in electron supply to the nitrite reductases of the DNRA pathway. Friedl et al. also reported that high labile $\mathrm{C}$ availability drives heterotrophic soil respiration, ultimately shifting $\mathrm{NO}_{3}^{-}$consumption from denitrification to DNRA [37]. The electron donors to acceptors is the primary factor influencing DNRA, and could be changed by adjusting operational parameters when DNRA is inhibited or promoted.

Furthermore, $\mathrm{N}_{2} \mathrm{O}$ is an important carbon dioxideequivalent greenhouse gas which is produced in nitrification and denitrification processes. This study was driven by the question of whether it is produced during bacterial growth with nitrate as the sole nitrogen source. Results show that $0.7 \%$ of influent nitrate were converted to $\mathrm{N}_{2} \mathrm{O}$ for $\mathrm{A} / \mathrm{O}$ sludge and anoxic sludge with nitrate as a nitrogen source, which was lower than the value of constructed wetland $(1.44 \%-5.08 \%)$ [38] and in anoxic tank of full-scale $\operatorname{WWTP}(3.5 \%)[39,40]$. DNRA was not a source of $\mathrm{N}_{2} \mathrm{O}$ [41]. $\mathrm{N}_{2} \mathrm{O}$ load emitted was mainly related to the variability of the influent $\mathrm{C} / \mathrm{N}$ ratio $[38,42]$. It is more than the system dominant in DNRA $(0.035 \%)$ [18]. The results showed that using nitrate as the nutrient for bacterial growth and the DNRA process leads to a lower $\mathrm{N}_{2} \mathrm{O}$ production than the denitrification process. The fate of $\mathrm{N}_{2} \mathrm{O}$ was higher in low redox potentials [38], low $\mathrm{pH}$ [18] and low $\mathrm{C} / \mathrm{N}$ ratio $[38,42]$.

\section{Nitrogen Reduction Pathways}

To investigate the nitrate reduction pathways in activated sludge with nitrate as nutrient, the $\mathrm{C} / \mathrm{N}$ ratio of the influent was increased to 7 on day 60 , with $92 \mathrm{mg} / \mathrm{L}$ of nitrate and $42 \mathrm{mg} / \mathrm{L}$ of ammonia in the batch test. The reactors were cultivated with nitrate as the nitrogen source. The ammonia concentration decreased from 42 to $38 \mathrm{mg} / \mathrm{L}$ in the first $60 \mathrm{~min}$ and then increased up to $49 \mathrm{mg} / \mathrm{L}$ (Fig. 5). Results showed that the bacteria reduced a part of nitrate in the DNRA pathway. Compared to nitrate, bacteria primarily use ammonia for growth. The rate of nitrate reduction to ammonia via DNRA bacteria was lower than the consumption rate, which resulted in a decrease of ammonia in the first $60 \mathrm{~min}$. This also explains why ammonia could not be detected in both reactors in the first $60 \mathrm{~d}$. The DNRA rate was higher than the consumption rate in the following stage, which led to ammonia accumulation. This result also demonstrates that DNRA is not inhibited by the presence of ammonia. Numerous studies confirmed that DNRA is a common process in bacteria [18, 43, 44]. Based on our results, nitrate can be reduced via DNRA in both reactors, and the process

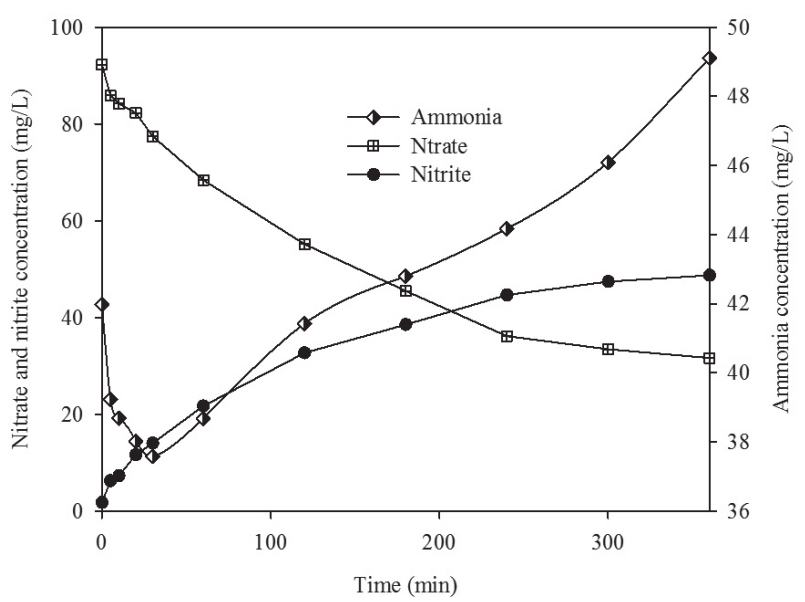

Fig. 5. Variation of nitrogen in the sludge slurry in the study of nitrate transformation pathway. 
itself was probably stimulated by the change of the nitrogen source and ageing of the sludge.

\section{Stoichiometry and Bacterial Reaction}

It is important to discuss the bacterial metabolisms with different nitrogen sources. Microorganisms prefer to use ammonia or organic nitrogen for biomass synthesis if available, because the status of organic nitrogen within the cells is the same as that of ammonia (-III), which is also demonstrated in Fig. 5. When an oxidized form of nitrogen is used, the microorganisms must reduce it to the (-III) oxidation state of ammonia. This process requires electrons and energy, thus reducing their availability for biomass synthesis [31]. For anoxic bacteria with ammonia as nutrient and nitrate as terminal electron acceptor in the activated sludge model 1 (ASM1), the heterotroph anoxic yield is $0.53 \mathrm{~g} \mathrm{COD} \cdot \mathrm{g}$ $\mathrm{COD}^{-1}$ for ordinary heterotrophic organisms (OHOs) [45]; the stoichiometric equations are as follows:

Catabolism $0.8 \mathrm{NO}_{3}^{-}+\mathrm{CH}_{2} \mathrm{O} \rightarrow 0.4 \mathrm{~N}_{2}+0.6 \mathrm{H}_{2} \mathrm{O}+\mathrm{CO}_{2}+0.8 \mathrm{OH}^{-}$

Anabolism $0.2 \mathrm{NH}_{3}+\mathrm{CH}_{2} \mathrm{O} \rightarrow 0.2 \mathrm{C}_{5} \mathrm{H}_{7} \mathrm{NO}_{2}+0.6 \mathrm{H}_{2} \mathrm{O}$

Total metabolism:

$0.106 \mathrm{NH}_{3}+\mathrm{CH}_{2} \mathrm{O}+0.376 \mathrm{NO}_{3}^{-} \rightarrow 0.106 \mathrm{C}_{5} \mathrm{H}_{7} \mathrm{NO}_{2}+0.6 \mathrm{H}_{2} \mathrm{O}+0.188 \mathrm{~N}_{2}+$ $+0.47 \mathrm{CO}_{2}+0.376 \mathrm{OH}^{-}$

When nitrate is the sole nitrogen source, the nitrogen should be reduced from the $+\mathrm{V}$ state to the -III state prior to assimilation. For the anoxic sludge used in this research, with nitrate as nutrient, the heterotroph anoxic yield was $0.30 \mathrm{~g} \mathrm{COD} \cdot \mathrm{g} \mathrm{COD} \mathrm{CO}^{-1}$, with the following metabolism:

Catabolism $\quad 0.8 \mathrm{NO}_{3}^{-}+\mathrm{CH}_{2} \mathrm{O} \rightarrow 0.4 \mathrm{~N}_{2}+0.6 \mathrm{H}_{2} \mathrm{O}+\mathrm{CO}_{2}+0.8 \mathrm{OH}^{-}$

Anabolism

$$
0.1429 \mathrm{NO}_{3}^{-}+\mathrm{CH}_{2} \mathrm{O} \rightarrow 0.1429 \mathrm{C}_{5} \mathrm{H}_{7} \mathrm{NO}_{2}+0.7143 \mathrm{H}_{2} \mathrm{O}+
$$$$
+0.1429 \mathrm{OH}^{-}+0.2858 \mathrm{CO}_{2}
$$

Total metabolism reaction

$$
\begin{aligned}
0.524 \mathrm{NO}_{3}^{-}+\mathrm{CH}_{2} \mathrm{O} & \rightarrow 0.232 \mathrm{~N}_{2}+0.06 \mathrm{C}_{5} \mathrm{H}_{7} \mathrm{NO}_{2}+0.648 \mathrm{H}_{2} \mathrm{O}+ \\
& +0.524 \mathrm{OH}^{-}+0.700 \mathrm{CO}_{2}
\end{aligned}
$$

Subsequently, $11.45 \%$ of the nitrate is converted to biomass, while the remaining biomass is reduced to nitrogen gas. This result is approximately in line with the nitrogen mass balance analysis.

For A/O sludge with nitrate as nutrient, the heterotroph yield was $0.35 \mathrm{~g} \mathrm{COD} \cdot \mathrm{g} \mathrm{COD}{ }^{-1}$. The catabolism and anabolism of sludge from $\mathrm{A} / \mathrm{O}$ sludge are the same as in the anoxic SBR (Eq. 8, Eq. 9), but the total stoichiometric equation is as follows:
Total metabolism reaction

$$
\begin{aligned}
0.486 \mathrm{NO}_{3}^{-}+\mathrm{CH}_{2} \mathrm{O} & \rightarrow 0.208 \mathrm{~N}_{2}+0.07 \mathrm{C}_{5} \mathrm{H}_{7} \mathrm{NO}_{2}+0.662 \mathrm{H}_{2} \mathrm{O} \\
& +0.486 \mathrm{OH}^{-}+0.660 \mathrm{CO}_{2}
\end{aligned}
$$

Microorganisms obtain their energy from oxidationreduction reactions for growth and maintenance. Bacterial growth involves two basic reactions: one for energy production and one for cellular synthesis. Our results showed that of all the COD removed from the reactors, $30-35 \%$ was incorporated into the newly synthesized biomass, while the rest was fully oxidized to $\mathrm{CO}_{2}$ for energy and denitrification.

Fig. 2 shows that when $1 \mathrm{~g}$ of nitrate was removed, $5.55 \mathrm{~g}$ and $5.41 \mathrm{~g}$ of COD were consumed by the sludge in the A/O and anoxic SBRs by day 60, respectively. These values were $5.31 \mathrm{~g}$ and $5.30 \mathrm{~g}$ when the nitrogen source was changed to ammonia, indicating the different metabolic pathways in the systems with nitrate or ammonia as nitrogen source. Based on the anabolism equations (Eqs. 6 and 8) for the production of $1 \mathrm{~g}$ of cells, $1.97 \mathrm{~g}$ COD and $0.12 \mathrm{~g}$ nitrate nitrogen are needed when nitrate is the sole nitrogen source. When the heterotrophic bacteria used ammonia as nitrogen source, $1.40 \mathrm{~g}$ COD were needed for the synthesis of $1 \mathrm{~g}$ of cells, while $0.34 \mathrm{~g}$ COD were needed for denitrifying $0.12 \mathrm{~g}$ nitrate nitrogen. Consequently, an additional $0.57 \mathrm{~g}$ COD is needed for the synthesis of $1 \mathrm{~g}$ of cells when using nitrate as compared to ammonia. The bacteria need an additional $1.14 \mathrm{~g} \mathrm{COD} / \mathrm{g} \mathrm{NO}_{3}^{-}$in DNRA than denitrification compared with denitrification. Thus, the amounts of COD used to reduce 1 gram of nitrate in both reactors were higher than those used in the same systems with ammonia as nutrient source.

\section{Conclusions}

This work set out to study the properties of heterotrophic growth at different nitrogen sources (ammonia and nitrate) in anoxic and A/O SBRs. Based on our results, heterotrophic bacteria performed similarly in both reactors, with a lag period of 8-9 $d$ in growth and of 13-15 $\mathrm{d}$ in sludge performance in terms of COD and nitrogen removal due to the change of the nitrogen source from ammonia to nitrate. Nitrate as nitrogen source had a negative effect on the synthesis of cell proteins and phosphorus, but a positive effect on polysaccharides and lipid synthesis. A similar pattern was observed in EPS and SMP production. The nitrate as nutrient for cell growth was used via the DNRA pathway. The results of this study contribute to understanding the effect of nitrogen source on sludge properties and help uncover the utilization mechanism of nitrogen source in the wastewater treatment process without ammonia as a nitrogen source. 


\section{Acknowledgements}

The author is grateful for the School of environmental and municipal engineering in Xi'an University of Architecture and Technology. Our thanks for funding from the National Natural Science Foundation of China (grant Nos. 50838005 and 51509200) and the National Water Pollution Control and Management Technology Major Projects of China (No. 2009ZX07317-009).

\section{Conflict of Interest}

The authors declare no conflict of interest.

\section{References}

1. LU W.-W., ZHANG H.-L, SHI W.-M. Dissimilatory nitrate reduction to ammonium in an anaerobic agricultural soil as affected by glucose and free sulfide. European Journal of Soil Biology, 58, 98, 2013.

2. ROBERTS K.L., KESSLER A.J., GRACE M.R., COOK P.L.M. Increased rates of dissimilatory nitrate reduction to ammonium (DNRA) under oxic conditions in a periodically hypoxic estuary. Geochimica et Cosmochimica Acta, 133 (15), 313, 2014.

3. HOU L., LIU M., CARINI S.A., GARDNER W.S. Transformation and fate of nitrate near the sediment-water interface of Copano Bay. Cont. Shelf Res., 35, 86, 2012.

4. BELAY N., JUNG K.Y., RAJAGOPAL B.S., KREMER J.D., DANIELS L. Nitrate as sole nitrogen source for methanococcus thermolithotrophicus and its effect on growth of several methanogenic bacteria. Current Microbiology, 21, 193, 1990.

5. FLIPPIN T.H., MOYE D., ECKENFELDER W.W. Benefits of using nitrate as nutrient in activated sludge treatment system J. Proceedings of the Water Environment Federation, Industrial Wastes, 9, 888, 2002.

6. VAN DEN BERG E.M., VAN DONGEN U., ABBAS B., VAN LOOSDRECHT M.C.M. Enrichment of DNRA bacteria in a continuous culture. International Society for Microbial Ecology, 9, 2153, 2015.

7. BOOPATHY R., KULPA C.F. Trinitrotoluene (TNT) as a sole nitrogen source for a sulfate reducing bacterium Desulfovibrio $\mathrm{sp}$, (B strain) isolated form an anaerobic digester. Current microbiology, 25, 235, 1992.

8. HUYGENS D., RÜTTING T., BOECKX P., Van CLEEMPUT O., GODOY R., MÜLLER C. Soil nitrogen conservation mechanisms in a pristine south Chilean Nothofagus forest ecosystem. Soil Biology and Biochemistry, 39, 2448, 2007.

9. NIZZOLI D., CARRARO E., NIGRO V., VIAROLI P. Effect of organic enrichment and thermal regime on denitrification and dissimilatory nitrate reduction to ammonium (DNRA) in hypolimnetic sediments of two lowland lakes. Water Research, 44, 2715, 2010.

10. DONG L.F., SOBEY M.N., SMITH C.J., RUSMANA I., PHILLIPS W., STOTT A., OSBORN A.M., NEDWELL D.B. Dissimilatory reduction of nitrate to ammonium, not denitrification or anammox, dominates benthic nitrate reduction in tropical estuaries. Limnol. Oceanogr., 56 (1), 279, 2011.
11. SONG G.D., LIU S.M., MARCHANT H., KUYPERS M.M.M., LAVIK G. Anammox, denitrification and dissimilatory nitrate reduction to ammonium in the East China Sea sediment. Biogeosciences, 10 (11), 6851, 2013.

12. WINKLER M.K.H., KLEEREBEZEM R., VAN LOOSDRECHT M.C.M. Integration of anammox into the aerobic granular sludge process for main stream wastewater treatment at ambient temperatures. Water Resarch, 46, 136, 2012.

13. ALGAR C.K., VALLINO J.J. Predicting microbial nitrate reduction pathways in coastal sediments. Aquat. Microb. Ecol., 71, 223, 2014.

14. CASTRO-BARROS C.M., JIA M., VAN LOOSDRECHT M. C.M., VOLCKE E. I. P., WINKLER M. K. H. Evaluating the potential for dissimilatory nitrate reduction by anammox bacteria for municipal wastewater treatment. Bioresource Technology, 233, 363, 2017.

15. TOBIAS C.R., ANDERSON I.C., CANUEL E.A., MACKO S.A. Nitrogen cycling through a fringing marsh-aquifer ecotone. Mar. Ecol. Prog. Ser., 210, 25, 2001.

16. KASPAR H.F., TIEDJE J.M., FIRESTONE R.B. Denitrification and Dissimilatory Nitrate Reduction to Ammonium in Digested Sludge. Can. J. Microbio., 27 (9), 878, 1981.

17. XIE L., JI C., WANG R., ZHOU Q. Nitrate reduction pathway in an anaerobic acidification reactor and its effect on acid fermentation. Journal of Bioscience and Bioengineering, 119 (1), 95, 2015.

18. JAHANGIR M.M.R., FENTON O., MÜLLER C., HARRINGTON R., JOHNSTON P., RICHARDS K.G. In situ denitrification and DNRA rates in groundwater beneath an integrated constructed wetland. Water Research, 111, 254, 2017.

19. CLESCERI L.S., GREENBERG A.E., EATON A.D. Standard Methods for the Examination of Water and Wastewater. $20^{\text {th }}$, ed. American Public Health Association: Washington, DC, USA, pp. 2-54-4-148, 1998.

20. FRØLUND B., PALMGREN R., KEIDING K., Nielsen P.H. Extraction of extracellular polymers from activated sludge using a cation exchange resin. Water Resarch, 30, $1749,1996$.

21. WANG B.B., LIU X.T., CHEN J.M., PENG D.C., HE F. Composition and functional group characterization of extracellular polymeric substances (EPS) in activated sludge: the impacts of polymerization degree of proteinaceous substrates. Water research 129, 133, 2018.

22. FRØLUND B., GRIEBE T., NIELSEN P. H. Enzymatic activity in the activated-sludge floc matrix. Appl. Environ. Microbiol., 43, 755, 1995.

23. DUBOIS M., GILLES K.A., HAMILTON J.K., REBERS P.A., SMITH F. Colorimetric method for determination of sugars and related substances. Anal. Chem., 28 (3), 350, 1956.

24. LIU H., FANG H.H.P. Extraction of extracellular polymeric substances (EPS) of sludges. J. Biotechnol., 95, 249, 2002.

25. VANDEKERCKHOVE T.G.L., MULDER C.D., BOON N., VLAEMINCK S.E. Temperature impact on sludge yield, settleability and inetics of three heterotrophic conversions corroborates the prospect of thermophilic biological nitrogen removal. Bioresource Technology, 269, 104, 2018. 
26. XU R., FAN Y., WEI Y., WANG Y., LUO N., YANG. M., YUAN X., YU R. Influence of carbon sources on nutrient removal in A2/O-MBRs: Availability assessment of internal carbon source. Journal of Environmental Sciences, 48, 59, 2016.

27. NI B.J., YU H.Q. Microbial products of activated sludge in biological wastewater treatment systems: a critical review. Crit. Rev. Env. Sci. Tec., 42, 187, 2012.

28. DU R., CAO S., LI B., ZHANG H., WANG S., PENG Y. Synergy of partial-denitrification and anammox in continuously fed upflow sludge bed reactor for simultaneous nitrate and ammonia removal at room temperature. Bioresource Technology, 274, 386, 2019.

29. YIN C., MENG F., CHEN G.H. Spectroscopic characterization of extracellular polymeric substances from a mixed culture dominated by ammonia-oxidizing bacteria. Water Resarch, 68 (641), 740, 2015.

30. WANG B.-B., CHANG Q., PENG D.-C, HOU Y.-P., LI H.J., PEI L.-Y. A new classification paradigm of extracellular polymeric substances (EPS) in activated sludge:Separation and characterization of exopolymers between floc level and microcolony level. Water Resarch, 64, 53, 2014.

31. RITTMANN B.E., MCCARTY P.L. Stoichiometry and bacteria energetics. In: Environmental biotechnology: principles and applications. McGraw-Hill, NewYork, 2001.

32. ROLAND F.A.E., DARCHAMBEAU F., BORGES A.V., MORANA C., BRABANDERE L.D., THAMDRUP B., CROWE S.A. Denitrification, anaerobic ammonium oxidation, and dissimilatory nitrate reduction to ammonium in an East African Great Lake (Lake Kivu). Limnology and Oceanography, 63 (2), 687, 2017.

33. RAHMAN M.M., ROBERTS K.L., WARRY F., GRACE M.R., COOK P.L.M. Factors controlling dissimilatory nitrate reduction processes in construced stormwater urban wetlands. Biogechemistry, 142 (3), 375, 2019.

34. MINICK K.J, PANDEY C.B, FOX T.R, SUBEDI S. Dissimilatory nitrate reduction to ammonium and $\mathrm{N}_{2} \mathrm{O}$ flux: effect of soil redox potential and $\mathrm{N}$ fertilization in loblolly pine forests. [J] Biology and Fertility of Soils, 52 (5), 601, 2016.

35. ZHANG W., LI X., LIU T., LI F. Enhanced Nitrate Reduction and Current Generation by Bacillus sp. in the Presence of Iron Oxides. Journal of Soils Sediments, 12 (3), 354, 2012.

36. GIBLIN A.E., WESTON N.B., BANTA G.T., TUCKER J., HOPKINSON C.S. The effects of salinity on nitrogen losses from an Oligohaline Estuarine sediment. Estuaries and Coasts, 33(5), 1054, 2010.
37. FRIEDL J., DE ROSA D., ROWLINGS D.W., GRACE P.R., MÜLLER C. Dissimilatory nitrate reduction to ammonium (DNRA), not denitrification dominates nitrate reduction in subtropical pasture soils upon rewetting. Soil Biology and Biochemistry, 125, 340, 2018.

38. LI M., WU H., ZHANG J., NGO H.H., GUO W., KONG Q. Nitrogen removal and nitrous oxide emission in surface flow constructed wetlands for treating sewage treatment plant effluent: Effect of $\mathrm{C} / \mathrm{N}$ ratios. Bioresource Technology, 240, 157, 2017.

39. FOLEY J., DE HAAS D., YUAN Z., LANT P. Nitrous oxide generation in full-scale biological nutrient removal wastewater treatment plants. Water Research, 44 (3), 831, 2010.

40. SPINELLI M., EUSEBI A.L., VASILAKI V., KATSOU E., FRISON N.,CINGOLANI D., FATONE F. Critical analyses of nitrous oxide emissions in a full scale activated sludge system treating low carbon-to-nitrogen ratio wastewater. Journal of Cleaner Production, 190 (20), 517, 2018.

41. CHEN Z., WANG C., GSCHWENDTNER S., WILLIBALD G., UNTEREGELSBACHER S., LU H., KOLAR A., SCHLOTER M., BUTTERBACHBAHL K., DANNENMANN M. Relationships between denitrification gene expression, dissimilatory nitrate reduction to ammonium and nitrous oxide and dinitrogen production in montane grassland soils. Siol Biology and Biochemistry, 87, 67, 2015.

42. CONTHE M., LYCUS P., ARNTZEN M. Ø., DA SILVA A.R., FROSTEGÅRD Å., BAKKEN L.R., KLEEREBEZEM R., VAN LOOSDRECHT M.C.M. Denitrification as an $\mathrm{N}_{2} \mathrm{O}$ sink. Water Research 151 (15), 381, 2019.

43. HARDISON A.K., ALGAR C.K., GIBLIN A.E., RICH J.J. Influence of organic carbon and nitrate loading on partitioning between dissimilatory nitrate reduction to ammonium (DNRA) and $\mathrm{N}_{2}$ production. Geochimica et Cosmochimica Acta, 164, 146, 2015.

44. KRAFT B., TEGETMEYER H.E., SHARMA R., KLOTZ M.G., FERDELMAN T.G., HETTICH R.L., GEELHOED J.S., STROUS M. The environmental controls that govern the end product of bacterial nitrate respiration. Science, 345 (6197), 676, 2014.

45. MULLER A., WENTZEL M.C., LOEWENTHAL R.E., EKAMA G.A. Heterotroph anoxic yield in anoxic aerobic activated sludge systems treating municipal wastewater. Water Resarch, 37 (10), 2435, 2003. 